\title{
The impact of the first wave of the COVID-19 pandemic on employment and firm revenues in Hungary
}

\author{
JÁNOS KÖLLŐ ${ }^{1 *}$ (1) and BALÁZS REIZER ${ }^{1,2}$ (1)
}

${ }^{1}$ Institute of Economics, Centre for Economic and Regional Studies, Tóth Kálmán u. 4, H-1097, Budapest, Hungary

${ }^{2}$ Institute of Economics and Public Policy, Department of Economic Policy and Labour Economics, Corvinus University of Budapest, Budapest, Hungary

Received: July 21, 2021 - Revised manuscript received: August 5, 2021 - Accepted: August 15, 2021

(c) 2021 Akadémiai Kiadó, Budapest

\begin{abstract}
Relying on the Labour Force Survey and the monthly revenue statistics of the Hungarian Central Statistical Office, we assess the immediate economic impact of the first wave of the COVID-19 pandemic in the first two quarters of 2020. We first analyse the role of job loss, working time reduction, downtime, and telework in adjustment to the crisis. The findings reveal an even more serious setback and increase in inequality than in 2008-2009. School leavers, young workers and unskilled laborers were particularly severely affected. Graduates were less likely to lose their jobs, more likely to switch to telework, and their employers faced a smaller decrease in sales revenue. The revenues of foreign-owned exporters fell more than the average in March but recovered by June. The decline experienced by businesses in the Hungarian ownership was slower but more prolonged.
\end{abstract}

\section{KEYWORDS}

COVID, employment, firm revenue

\section{JEL CLASSIFICATION INDICES}

E0, J0, LO

*Corresponding author. E-mail: kollo.janos@krtk.hu 


\section{INTRODUCTION}

The COVID epidemic reached Hungary in March 2020. In mid-March, the government ordered distance education, closed catering facilities, and introduced a lockdown. The first wave of the pandemic was far less severe than the second and third ones (a death toll of only 586 in MarchJuly 2020 compared to 29,403 between September 2020 and July 2021). At the same time, the economic impact was most substantial during the first wave. Registered unemployment jumped from 248 thousand in June 2019 to 376 thousand in June 2020 but fell to 266 thousand by June 2021. The GDP shrank by $14.1 \%$ in April-June 2020 but nearly recovered by the end of the second wave (in $2021 \mathrm{Q} 1$, it stood at $98.2 \%$ of the $2020 \mathrm{Q} 1$ level). ${ }^{1}$ It is hard to tell if this asymmetry is explained by moderate exposure to COVID and over-reacting in early 2020 versus a costly but successful attempt to control the epidemic. Whatever was the reason, the price paid was painfully high.

Even though restrictions were only introduced in the second half of March, aggregate labour market data for the whole of the first quarter were alarming: the share of workers becoming unemployed or economically inactive rose substantially, as seen in the left panel of Fig. 1.

Outflows from employment continued to increase in the second quarter (April-June): the share of those who became inactive was nearly double the level recorded in the previous years, while the percentage of those who became unemployed more than doubled. Inflows into employment could not offset the outflows, as seen in the right-hand panel of Fig. 1.

Financial data also show a significant drop. The sales revenues of businesses observed in the monthly statistics (OSAP 2235) increased continuously after 2011. However, they fell sharply during the lockdown, from 3,500 billion HUF in March and under 2,500 billion HUF in April. A fast recovery followed the dramatic decline: revenues rose significantly, above 3,000 billion HUF in two months; however, it did not reach its earlier levels over the summer.

Our paper relies on individual and firm data to assess the impact of the crisis. One of our sources is the Labour Force Survey (LFS) of the Hungarian Central Statistical Office (HCSO), which provides individual-level data on labour market status, actual and usual working time, occupation, and essential characteristics (like size, sector and ownership) of the employers. In recent years, the survey covered between 40 and 50 thousand individuals quarterly. The other source we rely on is the monthly revenue statistics (HCSO OSAP 2235), which contains monthly revenue data of 4,000 manufacturing firms.

The pandemic did not affect the various groups of society equally: 1) For employees with higher education degrees, it was easier to endure the crisis. They were less likely to lose their jobs, and their employers experienced a less severe loss in revenues. 2) Foreign-owned and exporting firms had a very substantial but mainly temporary setback, and their revenues had recovered primarily in levels similar to the pre-crisis levels. By contrast, the decline experienced by the firms of Hungarian ownership took place more slowly, and no recovery was seen. Accordingly, more people lost their jobs at these businesses. 3) As expected, sectors with a more significant proportion of workers able to switch to remote work endured the crisis more quickly.

\footnotetext{
${ }^{1}$ For the unemployment data see https://nfsz.munka.hu/tart/munkaeropiac. The GDP figures (http://www.ksh.hu/stadat_ files/gdp/hu/gdp0086.html) are seasonally adjusted and measured at constant prices. Statistics for 2021 Q2 are not available yet.
} 

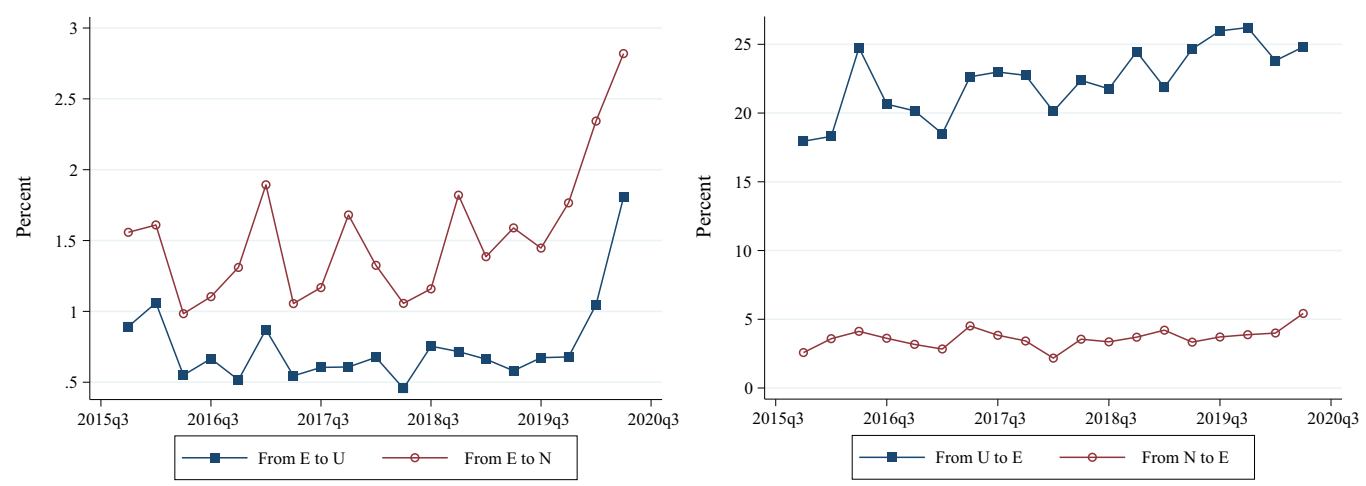

Fig. 1. Flows between employment, unemployment, and inactivity

Source: Labour Force Survey (LFS) of the Hungarian Central Statistical Office (HCSO). Version maintained by the Centre for Economic and Regional Studies (CERS) Databank.

Note: The initial value of the upper curve of the left-hand side panel shows that about $1.5 \%$ of those in employment in 2015 Q3 were reported to be inactive in 2015 Q4. The rest of the data should be interpreted similarly. The estimates of flows, harmonised with changes in stocks, were prepared by Cseres-Gergely (2011), using the method of raking, for which we sincerely thank him.

This is equally true if the transition to telework is examined at the enterprise, individual or sector level. 4) The above three results have something in common: the members of society who were in a better position before the crisis could better adapt to the crisis.

Based on the LFS, Section 2 provides an overview of trends in employment. In Section 3, the turnover of manufacturing firms is analysed relying on revenue statistics. Section 4 summarises the results. We regard the paper as a statistical report, which offers details not available in the publications of the HCSO and other data owners. We do not aim at exploring the voluminous literature published about the subject over the past one and a half years.

\section{EMPLOYMENT, WORKING TIME, AND TELEWORK IN THE FIRST HALF OF 2020}

\subsection{Concepts and measurement}

According to the LFS, employees (i) undertook at least one hour of gainful work during the week before the survey, or (ii) were only temporarily away from their job. The latter category had no importance in Hungary in "peacetime" as the share of those employed on such terms did not exceed $1.5-2 \%$ in the first and second quarters, over the past ten years. By contrast, there must have been many who were unable to work during the pandemic while their employment relationship was maintained. The LFS measures the number of hours worked during the reference week and usual weekly hours. Therefore, it is possible to consider the number of 
employees not performing work or working less than normal. The LFS also allows measuring employment in full-time equivalent (FTE) units instead of headcount. ${ }^{2}$

Consideration should also be given to the periods compared. According to data on flows between labour market states, the labour market situation already deteriorated in the first quarter, therefore the periods of January-February, March, and April-June will be compared in the following. March cannot be merged with the second quarter because using differing weights would cause significant complications. For the number of observations in the three periods, see the Appendix. ${ }^{3}$

It must be considered that the measurement error is rather large due to the limited size of the LFS. The sample most suitable for analysing short-term labour market developments (workingage persons except full-time students) is not large, especially not in March, thus this month is excluded from the tables presenting group breakdowns, and we only attribute importance to the significant changes.

Another source of uncertainty is that the survey itself did not remain immune to the pandemic either. The LFS is a rotating panel with each selected household participating in the survey for six consecutive quarters and then replaced by a randomly selected new one. In 2020 Q2, the HCSO kept the outgoing cohort in the survey, but even so, the first-quarter sample of 48 thousand shrank to 43 thousand in the second quarter, due to an increased attrition rate in each cohort. The effects of rotation and dropouts are usually treated via reweighting (Mihályffy 1995; Molnár 2005; Cseres-Gergely 2011). However, due to the vast number of those dropping out of the survey, and their unusual composition, representativity was more difficult to ensure in the spring of 2020 .

\subsection{Trends in aggregate employment}

Employment by the standard ILO-OECD definition decreased by 2.8 percentage points in April-June compared to January-February (Table 1). The share of those who undertook at least an hour of actual work during the reference week fell even more sharply, by 5.7 percentage points $(7.6 \%)$, with most of the decrease happening by the end of March. ${ }^{4}$

At the same time, the average weekly working time dropped by 3.5 hours. The decline was partly explained by more public holidays per weekdays in April-June - working time adjusted for that fell by 2.1 hours. After March, the proportion of employees who worked less than usual increased dramatically, from below $10 \%$ to over $30 \%$. Full-time equivalent employment, which best approximates the use of labour in the economy, plummeted by 9.3 percentage points if calculated using raw data and by 6.6 percentage points (9\%) if estimated using data adjusted for

\footnotetext{
${ }^{2}$ If in a micro-economy two out of four people work, one of them 40 hours a week and the other 20 hours, the employment rate is $50 \%$ but FTE equals only to $1.5 / 4=37.5 \%$.

${ }^{3}$ Since the LFS only becomes representative when the entire quarterly sample is queried, the timing of interviews could affect the results when comparing January-February, March and April-June. If, for example, the inhabitants of small villages were always included in the third month of a quarter (which is not the case), their absence in the first and presence in the second period would distort comparison over time and would paint a bleaker picture of employment than it is. In view of this (moderate) risk, we also report comparisons based on quarterly data.

${ }^{4}$ The fraction of workers qualified as employed without working at least one hour amounted to $3.4 \%$ during JanuaryFebruary compared to $7.4 \%$ in April-June.
} 
calendar effects. ${ }^{5}$ These figures reveal an even greater shock than the one in 2008-2010, during and after the international financial crisis. Then, in the first four months of that crisis (between October 2008 and February 2009), the employment rate decreased by 2.2 percentage points, and the share of those who worked at least one hour fell by 2.6 percentage points only. ${ }^{6}$

The data in Table 1 ignore the effect of seasonality. This, we believe, is acceptable because employment in the second quarter was always higher than in the first quarter ever since 1992 (the launch of the LFS). If seasonality were considered, the decline in employment would be even more significant. Furthermore, paid leave, granted because of the lockdown, had been fully used up by the middle of the second quarter at the latest and therefore could not significantly affect the number of employees working zero hours. We can also rule out that zero-hours were explained by a surge in holiday travels (in a period of strict lockdown).

The detrimental effect of the lockdown on jobs was mitigated by work from home. The proportion of those doing telework during the four weeks preceding the survey ranged between 1 and $2 \%$ in the past twenty years. However, as seen in the bottom block of Table 1, while $2.5 \%$ of employees working at least one hour did telework in January-February, this proportion rose to $16.5 \%$ in the second quarter.

\subsection{Employment rates by social groups}

The two regression equations of Table 2 use a linear probability model to estimate the effects of individual characteristics on the probability of working at least one hour in January-February and April-June 2020. The final column of the table describes whether the parameters of the two cross-sectional equations are statistically different. Again, the sample includes the population aged 15-64 years, not in full-time education.

Female employment suffered more than males. The employment rate of women with children aged 0-6 years (with or without older children) was low in both periods but somewhat improved compared to men and the two other groups of women. It must be noted, though, that the working mothers of young children could possibly secure childcare before and during the pandemic.

Compared with the 30-40 years age group, the employment chances of the population aged 15-20 years deteriorated dramatically, and that of the 20-29 years age group declined less seriously but still significantly. The situation of those aged over 50 and especially those aged over 60 years improved compared to the middle-aged.

The parameters on educational attainment indicate that the advantage of those with general upper secondary school (gymnasium) attainment decreased, while the relative position of university graduates improved.

Employment rates declined more in large cities and Budapest than in towns and villages, even though the employment and qualification-related conditions for telework are more

\footnotetext{
${ }^{5}$ When comparing entire quarters, FTE, adjusted for calendar effect, fell by 5.5 percentage points or $7.7 \%$. Nevertheless, the data is distorted because the labour market situation had already deteriorated in March due to the lockdown, and therefore, the first quarter cannot entirely be regarded as a "pre-pandemic period".

${ }^{6}$ Authors' calculations based on the version of the LFS of the HCSO maintained by the CERS Databank.
} 
Table 1. Key labour market indicators in the first half of 2020

\begin{tabular}{|l|c|c|c|c|}
\hline & $\begin{array}{c}\text { January-February } \\
\text { (1) }\end{array}$ & $\begin{array}{c}\text { March } \\
\text { (2) }\end{array}$ & $\begin{array}{c}\text { April-June } \\
\text { (3) }\end{array}$ & $\begin{array}{c}\text { Change } \\
\text { (3)-(1) }\end{array}$ \\
\hline Employment (Population=100\%) $^{\text {a }}$ & & & & \\
\hline Employed based on the IL0-0ECD definition & 77.6 & 76.1 & 74.8 & -2.8 \\
\hline Worked at least one hour & 75.0 & 70.1 & 69.3 & -5.7 \\
\hline $\begin{array}{l}\text { Weekly hours worked by those in } \\
\text { employment }\end{array}$ & & & & \\
\hline Raw & 37.6 & 36.5 & 34.1 & -3.5 \\
\hline Adjusted for calendar effect ${ }^{\mathrm{b}}$ & 37.6 & 35.7 & 35.5 & -2.1 \\
\hline Worked less than usual (\%) & & 10.1 & 31.2 & 21.2 \\
\hline $\begin{array}{l}\text { Full-time equivalent employment (FTE) } \\
\text { (Population=100\%), }^{\mathrm{a}}\end{array}$ & 9.0 & & & \\
\hline Using raw working hours data & 73.0 & 68.5 & 63.7 & -9.3 \\
\hline Using adjusted working hours data & 73.0 & 67.9 & 66.4 & -6.6 \\
\hline $\begin{array}{l}\text { Telework (Worked at least } \\
\text { one hour = 100\%) }\end{array}$ & & & & \\
\hline Regularly & 1.0 & 1.5 & 6.9 & 5.8 \\
\hline Occasionally & 1.5 & 4.1 & 9.6 & 8.1 \\
\hline Total & 2.5 & 5.6 & 16.5 & 13.9 \\
\hline
\end{tabular}

Source: Version of the LFS of the HCSO maintained by the CERS Databank. Observations were weighted by the appropriate quarterly weights.

a) Population: Aged 15-64, not in full-time education.

b) Considering that the monthly working time was $\mathbf{2 1 . 5}$ days on average in January-February, 22 days in March, and 20.67 days in April-June.

c) Among employees as per the LFS definition, excluding the $3-4 \%$ of employees with "highly variable" work hours. Population aged 15-64, not in education.

d) FTE measures the ratio of actual working hours to a hypothetical maximum reached if all members of the labour force worked 40 hours a week.

favourable. This seems to be counteracted by the dominance of some strongly affected sectors, like tourism, hotels and restaurants, non-food retail, and personal and cultural services. The approximately 14\% Roma-non-Roma employment gap did not change significantly. ${ }^{7}$

\footnotetext{
${ }^{7}$ There are 674 and 656 observations in the two periods considered of individuals identifying themselves as Roma primarily or secondarily.
} 
Table 2. Regression estimation of employment chances, 2020

\begin{tabular}{|c|c|c|c|}
\hline & January-February & April-June & Chi2 \\
\hline \multirow[t]{2}{*}{ Female, without a child } & $-0.084^{* * *}$ & $-0.110^{* * *}$ & $4.44^{* *}$ \\
\hline & $(9.80)$ & $(12.32)$ & \\
\hline Female, with children older & $-0.068^{* * *}$ & $-0.089^{* * *}$ & 1.47 \\
\hline than 6 (only) & $(5.28)$ & (7.31) & \\
\hline Female, with at least one child & $-0.480^{* * *}$ & $-0.439^{* * *}$ & $3.36^{*}$ \\
\hline younger than 6 & $(29.13)$ & $(29.19)$ & \\
\hline \multirow[t]{2}{*}{$15-19$ years old } & $-0.376^{* * *}$ & $-0.494^{* * *}$ & $6.51^{* * *}$ \\
\hline & $(8.44)$ & $(23.21)$ & \\
\hline \multirow[t]{2}{*}{$20-29$ years old } & $-0.045^{* * *}$ & $-0.077^{* * *}$ & $3.49^{*}$ \\
\hline & (3.88) & $(6.13)$ & \\
\hline \multirow[t]{2}{*}{$40-49$ years old } & 0.012 & $0.033^{* * *}$ & 1.93 \\
\hline & $(1.20)$ & $(3.09)$ & \\
\hline \multirow[t]{2}{*}{$50-59$ years old } & $-0.060^{* * *}$ & $-0.031^{* * *}$ & $3.42^{*}$ \\
\hline & $(5.40)$ & (2.67) & \\
\hline \multirow[t]{2}{*}{$60-64$ years old } & $-0.421^{* * *}$ & $-0.359^{* * *}$ & $9.09^{* * *}$ \\
\hline & $(27.95)$ & $(24.65)$ & \\
\hline \multirow[t]{2}{*}{ Vocational school } & $0.156^{* * *}$ & $0.151^{* * *}$ & 0.06 \\
\hline & $(12.37)$ & $(12.65)$ & \\
\hline \multirow[t]{2}{*}{ Gymnasium (upper-secondary) } & $0.182^{* * *}$ & $0.132^{* * *}$ & $4.97^{* *}$ \\
\hline & $(11.55)$ & $(8.74)$ & \\
\hline \multirow[t]{2}{*}{ Vocational upper-secondary } & $0.205^{* * *}$ & $0.200^{* * *}$ & 0.10 \\
\hline & (15.17) & (15.68) & \\
\hline \multirow[t]{2}{*}{ College } & $0.242^{* * *}$ & $0.256^{* * *}$ & 0.49 \\
\hline & $(16.08)$ & (18.29) & \\
\hline \multirow[t]{2}{*}{ University } & $0.251^{* * *}$ & $0.299^{* * *}$ & $4.83^{* *}$ \\
\hline & (15.61) & (19.59) & \\
\hline \multirow[t]{2}{*}{ Roma } & $-0.147^{* * *}$ & $-0.130^{* * *}$ & 0.29 \\
\hline & $(5.87)$ & $(5.00)$ & \\
\hline \multirow[t]{2}{*}{ County capitals } & 0.003 & $-0.027^{* * *}$ & $4.57^{* *}$ \\
\hline & $(0.26)$ & $(2.74)$ & \\
\hline
\end{tabular}


Table 2. Continued

\begin{tabular}{|l|c|c|c|}
\hline & January-February & April-June & Chi2 \\
\hline Budapest & 0.015 & $-0.024^{*}$ & $4.54^{* *}$ \\
\hline & $(1.17)$ & $(1.80)$ & \\
\hline $2^{\text {nd }}$ month of the quarter & $0.033^{* * *}$ & $0.041^{* * *}$ & \\
\hline & $(4.53)$ & $(4.53)$ & \\
\hline $3^{\text {rd }}$ month of the quarter & & $0.068^{* * *}$ & \\
\hline & & $(7.77)$ & \\
\hline Constant & $0.716^{* * *}$ & $0.644^{* * *}$ & \\
\hline & $(52.28)$ & $(45.73)$ & \\
\hline$R^{2}$ & 0.24 & 0.21 & \\
\hline Number of observations & 18,353 & 23,870 & \\
\hline
\end{tabular}

Source: Version of the LFS of the HCSO maintained by the CERS Databank.

Note: ${ }^{*} p<0.1$; $^{* *} p<0.05$; ${ }^{* * *} p<0.01$. T-values are shown in brackets. Chi2 tests the equality of parameters across equations.

Reference categories: Male, aged 30-39 years, completed 0-8 grades, village or small town. Young children: Aged 0-6 years. Older children: Aged 7-18 years. Roma: Respondent identifying themselves as Roma primarily or secondly.

\subsection{The probability of job loss by employer characteristics and occupation}

The equations presented in Table 3 look at the impact of employer characteristics and occupation on the probability of job loss in three months following an employed person's first observation in January or February. By job loss, we mean the drop of actual working time from non-zero to zero, with or without the termination of the employment relationship. The sample includes respondents working at least one hour in the base period and included in the survey in April-June.

The probability of job loss is different in "peacetime" across occupations, sectors and company size: it is always higher for unskilled workers and project-based activities such as construction. Job loss rates seen during the pandemic are influenced by these time-independent effects. Therefore, data from 2020 are compared with corresponding data from 2019.

The aim is to see how likely it was for those in employment in January-February and working at least one hour to drop from this category in the second quarter. This is, in essence, estimating the odds of job loss within three months because those interviewed in January were included next in April, and those queried in February were included next in May in both 2019 and $2020 .^{8}$

\footnotetext{
${ }^{8}$ There are limitations to using LFS for reconstructing developments between two waves. Workers in employment during waves $t$ and $t+1$, may have been unemployed between the two interviews and if they became unemployed or changed jobs more than once, it is impossible to determine the length of unemployment. If only once, then it is possible to estimate based on the starting date of their employment ongoing in quarter $t+1$. However, the number of status changes is not known.
} 
Table 3. Estimates of three-month job loss in 2019 and 2020

\begin{tabular}{|c|c|c|c|}
\hline & 2019 & 2020 & Chi2 \\
\hline \multirow[t]{2}{*}{ Male } & -0.004 & $-0.036^{* * *}$ & $13.68^{* * * *}$ \\
\hline & $(1.07)$ & (4.69) & \\
\hline \multirow[t]{2}{*}{ Age } & $-0.009^{* * *}$ & $-0.023^{* * *}$ & $35.08^{* * *}$ \\
\hline & (7.44) & $(10.69)$ & \\
\hline \multirow[t]{2}{*}{ Age squared/100 } & $0.011^{* * *}$ & $0.028^{* * *}$ & $37.78^{* * *}$ \\
\hline & $(7.81)$ & $(11.30)$ & \\
\hline \multirow[t]{2}{*}{ Vocational school } & $-0.023^{* * *}$ & $-0.033^{* * *}$ & 0.63 \\
\hline & (3.35) & $(2.90)$ & \\
\hline \multirow[t]{2}{*}{ Gymnasium (upper-secondary) } & $-0.021^{* * *}$ & $-0.040^{* * *}$ & 1.18 \\
\hline & $(2.60)$ & $(2.65)$ & \\
\hline \multirow[t]{2}{*}{ Vocational upper-secondary } & $-0.018^{* *}$ & $-0.036^{* * *}$ & 1.55 \\
\hline & $(2.55)$ & $(2.88)$ & \\
\hline \multirow[t]{2}{*}{ College } & $-0.030^{* * *}$ & $-0.061^{* * *}$ & $3.68^{*}$ \\
\hline & $(4.05)$ & $(4.33)$ & \\
\hline \multirow[t]{2}{*}{ University } & $-0.028^{* * *}$ & $-0.099^{* * *}$ & $17.59^{* * *}$ \\
\hline & (3.44) & $(6.65)$ & \\
\hline \multirow[t]{2}{*}{ Hungarian-owned private firm } & $-0.013^{*}$ & 0.011 & $2.76^{*}$ \\
\hline & $(1.91)$ & $(0.86)$ & \\
\hline \multirow[t]{2}{*}{ Foreign-owned firm } & -0.004 & $0.055^{* * *}$ & $13.05^{* * *}$ \\
\hline & $(0.57)$ & (3.76) & \\
\hline \multirow[t]{2}{*}{ Mixed } & 0.006 & 0.008 & 0.03 \\
\hline & $(0.87)$ & $(0.72)$ & \\
\hline \multirow[t]{2}{*}{ 1-10 employees } & 0.006 & $0.038^{* * *}$ & $8.01^{* * * *}$ \\
\hline & $(1.07)$ & (3.73) & \\
\hline \multirow[t]{2}{*}{ 11-50 employees } & 0.002 & $0.016^{*}$ & 2.09 \\
\hline & $(0.44)$ & $(1.85)$ & \\
\hline \multirow[t]{2}{*}{ Size unknown } & $0.011^{*}$ & 0.008 & 0.05 \\
\hline & $(1.73)$ & $(0.75)$ & \\
\hline \multirow[t]{2}{*}{ Contact with consumers ${ }^{a}$} & 0.007 & 0.008 & 0.01 \\
\hline & $(1.43)$ & $(0.81)$ & \\
\hline
\end{tabular}


Table 3. Continued

\begin{tabular}{|c|c|c|c|}
\hline & 2019 & 2020 & Chi2 \\
\hline \multirow[t]{2}{*}{ Teamwork $^{\mathrm{a}}$} & -0.007 & 0.001 & 0.44 \\
\hline & $(1.30)$ & $(0.12)$ & \\
\hline \multirow[t]{2}{*}{ Job requires the presence of others ${ }^{\mathrm{a}}$} & -0.009 & -0.013 & 0.10 \\
\hline & $(1.63)$ & $(1.21)$ & \\
\hline \multirow[t]{2}{*}{ Public works participant } & $0.040^{* * *}$ & $0.067^{* * *}$ & 1.01 \\
\hline & $(2.68)$ & $(3.00)$ & \\
\hline \multirow[t]{2}{*}{ Motor industry } & 0.001 & $0.171^{* * *}$ & $41.93^{* * *}$ \\
\hline & $(0.13)$ & $(7.22)$ & \\
\hline \multirow[t]{2}{*}{ Other industry, energy } & 0.006 & $0.067^{* * *}$ & $16.31^{* * *}$ \\
\hline & $(0.70)$ & $(5.22)$ & \\
\hline \multirow[t]{2}{*}{ Communal services } & -0.002 & 0.016 & 0.65 \\
\hline & $(0.16)$ & $(0.86)$ & \\
\hline \multirow[t]{2}{*}{ Construction } & 0.008 & $0.054^{* * *}$ & $7.68^{* * *}$ \\
\hline & $(0.93)$ & (3.84) & \\
\hline \multirow[t]{2}{*}{ Trade } & 0.002 & $0.044^{* * *}$ & $6.30^{* *}$ \\
\hline & $(0.28)$ & (3.07) & \\
\hline \multirow[t]{2}{*}{ Transportation } & 0.004 & $0.062^{* * *}$ & $9.24^{* * *}$ \\
\hline & $(0.45)$ & (3.81) & \\
\hline \multirow[t]{2}{*}{ Services } & 0.003 & $0.129^{* * *}$ & $60.0^{* * *}$ \\
\hline & $(0.40)$ & $(9.21)$ & \\
\hline \multirow[t]{2}{*}{ Public administration } & 0.001 & $0.040^{* *}$ & $3.76^{*}$ \\
\hline & $(0.05)$ & $(2.38)$ & \\
\hline \multirow[t]{2}{*}{ Education } & -0.006 & $0.046^{* *}$ & $5.72^{* *}$ \\
\hline & $(0.53)$ & $(2.47)$ & \\
\hline \multirow[t]{2}{*}{ Healthcare } & -0.010 & $0.070^{* * *}$ & $13.93^{* * *}$ \\
\hline & $(0.90)$ & (3.78) & \\
\hline \multirow[t]{2}{*}{ County capital } & -0.004 & -0.007 & 0.14 \\
\hline & $(1.10)$ & $(1.05)$ & \\
\hline \multirow[t]{2}{*}{ Budapest } & $-0.011^{* *}$ & $0.020^{*}$ & $6.86^{\text {*** }}$ \\
\hline & $(2.43)$ & $(1.81)$ & \\
\hline
\end{tabular}

(continued) 
Table 3. Continued

\begin{tabular}{|l|c|c|c|}
\hline & 2019 & 2020 & Chi2 \\
\hline Job tenure (months) & $-0.000^{* *}$ & $-0.000^{* * *}$ & 23.73 \\
\hline & $(2.18)$ & $(6.93)$ & \\
\hline Constant & $0.218^{* * *}$ & $0.553^{* * * *}$ & \\
\hline & $(8.16)$ & $(11.09)$ & \\
\hline$R^{2}$ & 0.02 & 0.05 & \\
\hline$N$ & 10,770 & 10,777 & \\
\hline
\end{tabular}

Source: Version of the LFS of the HCSO maintained by the CERS Databank.

Notes: ${ }^{*} p<0.1 ;{ }^{* *} p<0.05 ;{ }^{* * *} p<0.01$. T-values are shown in brackets.

Sample: Employees, who undertook at least one hour of actual work in January-February. Dependent variable: 1 if the person obsenved three months later did not work at least one hour, and 0 otherwise.

Reference categories: Completed 0-8 grades, state-owned firm, agriculture, village or small town. Chi2 tests the equality of parameters across equations.

${ }^{\text {a }}$ We are using the American $0 *$ Net classification adapted to the Hungarian occupational classification system by Koren - Pető (2020).

The probability of job loss by the above definition was $2.8 \%$ in 2019 and $14 \%$ in 2020 . Table 3 presents the marginal effects controlling for gender, age and educational attainment.

The odds of job loss for men were equal to that of women in 2019, but lower in 2020. The parameters of age variables indicate the minimum odds of losing employment at age 40; however, the tails of the parabola were steeper in 2020 than in 2019. Allowing for constants and supposing all explanatory variables to be zero, the odds of losing employment were $5 \%$ higher during the pandemic among the 40-year-olds than one year prior, but they were $11-12 \%$ higher among 20-year-olds and 60-year-olds, respectively. The odds of job loss of those with lowersecondary and upper-secondary did not change relative to each other. Still, the situation of higher education graduates deteriorated less than the average.

While there was no difference by ownership in 2019, the foreign-owned firms dismissed their employees or reduced their working time to zero more than the state-owned firms and public institutions in 2020. Similarly, although differences by company size were negligible in 2019, a higher proportion of the workers in small enterprises lost (or left) their jobs during the pandemic compared to the workers at the average big firm. (Firm-level data will reveal that the situation of exporting companies among the latter group deteriorated considerably.) The odds of job loss increased dramatically in the motor industry and services. We discuss the developments in healthcare later.

\subsection{Differences in switching to telework}

The share of teleworkers increased by 13.9 percentage points between January/February and April/June, as presented in Table 1. In blue-collar occupations, the shift was negligible: less than one percentage point on average. By contrast, $9-10 \%$ of employees with a secondary school 
leaving certificate (Matura), 37.4\% of college graduates, and 50\% of university graduates worked from home in the second quarter. Workers in services, especially in education, switched to remote work in far greater than average numbers. Workers in industry, healthcare, and small enterprises, were less likely to start home office. Home office was more prevalent in the private sector than in the public sector or at state-owned companies. More people worked from home in Budapest and large cities than in small towns and villages. After controlling for occupational characteristics, no difference by gender and age is observed. As expected, fewer people worked from home in occupations where, according to the $\mathrm{O}^{*}$ Net classification, contact with consumers is essential, or the job tasks require the simultaneous presence of several individuals (see Table 4).

\subsection{Differences in adjustment by sectors and educational attainment}

Table 5 presents data on the patterns of adjustment in various sectors based on the combination of three indicators. The first column shows the likelihood of three-month job loss: what proportion of persons employed in January-February lost their jobs according to the observation three months later. (In this case, we do not differentiate between job holders undertaking at least one hour actual work and those who did not.) The second column indicates the share of jobholders who did not work during the week preceding the interview. Finally, the third column presents the share of those working from home as a percentage of those who worked a minimum of one hour. Sectors are ranked in the order of the job loss rate.

The highest job loss rate was seen in services including hotels, restaurants, and tourism. Even though the number of employees who were not dismissed but did not undertake actual work was above the average here, and the number of those working from home was extremely high, $7.2 \%$ of the employment relationships were terminated. The opportunity for remote work is limited in trade and the motor industry, contributing to their job loss rates being the second and third highest. Downtime affected $16 \%$ of the motor industry workers (by far the highest rate in the economy) that the government supported to an unknown extent. Communal services and transportation rank lowest in terms of job loss, along with education, where half of the employees worked from home in the second quarter..$^{9}$ The high $(10 \%)$ share of zero hours in healthcare may come as a surprise, but it was due to the administrative automatic dismissal of doctors older than 65 and the decline in patients at non-COVID wards and dental practices.

Finally, Table 6 presents the averages of the indicators discussed above broken down by educational attainment. Workers who completed primary school (lower-secondary education) had a high risk of losing their jobs or keeping their jobs but working zero hours. Due to lack of data, we do not know if they received their salaries, or at least part of it, in the second case. For workers with a vocational school qualification, the most likely outcome was losing their jobs or work.

In the two groups with a secondary school-leaving certificate (Matura), job loss rates were similar at five to six\%, while downtime and telework were relatively widespread at eight to eleven \%. For college and university graduates, switching to telework was the most frequent form of adjustment.

\footnotetext{
${ }^{9}$ In spite of the closure of schools, the proportion was far from one hundred\% probably because non-formal educators (music teachers, driving instructors etc.), educational service providers and the entire staff of schools and training centres including cleaners and maintenance staff also belong to the sector. $63.4 \%$ of teachers worked from home.
} 
Table 4. Factors affecting the probability of telework in April-June 2020

\begin{tabular}{|c|c|c|}
\hline \multicolumn{3}{|l|}{ Linear probability model } \\
\hline & Coefficient & $t$-value \\
\hline Male & -0.009 & -0.96 \\
\hline Age & 0.001 & 0.74 \\
\hline Age squared & -0.000 & -1.08 \\
\hline Vocational school & 0.006 & 1.14 \\
\hline Gymnasium (upper-secondary) & $0.067^{* * *}$ & 5.57 \\
\hline Vocational upper-secondary & $0.071^{* * *}$ & 8.26 \\
\hline College & $0.287^{* * *}$ & 19.16 \\
\hline University & $0.372^{* * *}$ & 21.12 \\
\hline Contact with consumers & $-0.033^{* * *}$ & -2.70 \\
\hline Teamwork & -0.012 & -0.92 \\
\hline Job requires the presence of others & $-0.044^{* * *}$ & -6.00 \\
\hline Firm size: $1-10$ employees & $-0.051^{* * *}$ & -4.29 \\
\hline Firm size: $11-50$ employees & $-0.040^{* * *}$ & -4.25 \\
\hline Firm size unknown & $-0.071^{* * *}$ & -5.72 \\
\hline Hungarian-owned private firm & $0.044^{* * *}$ & 2.93 \\
\hline Foreign-owned firm & $0.061^{* * *}$ & 3.40 \\
\hline Mixed & $0.039^{* * *}$ & 2.69 \\
\hline Motor industry & $-0.040^{* *}$ & -2.06 \\
\hline Other industry, energy & $-0.034^{*}$ & -2.80 \\
\hline Communal services & $0.050^{*}$ & 1.92 \\
\hline Construction & 0.004 & 0.90 \\
\hline Trade & -0.007 & -0.50 \\
\hline Transportation & -0.003 & -0.23 \\
\hline Services & $0.099^{* * *}$ & 6.57 \\
\hline Public administration & -0.005 & -0.29 \\
\hline Education & $0.273^{* * *}$ & 11.01 \\
\hline Healthcare & $-0.066^{* *}$ & -3.37 \\
\hline County capital & $0.022^{* *}$ & 2.44 \\
\hline Budapest & $0.122^{* * *}$ & 7.74 \\
\hline Constant & -0.016 & -0.35 \\
\hline
\end{tabular}

Source: Version of the LFS of the HCSO maintained by the CERS Databank.

Notes: ${ }^{*} \mathrm{p}<0.1 ;{ }^{* *} \mathrm{p}<0.05$; ${ }^{* * *} \mathrm{p}<0.01$. T-values are shown in brackets.

We are using a version of the $0 *$ Net classification adapted to the Hungarian occupational classification system by Koren - Petö (2020).

Reference categories: Completed 0-8 grades, over 50 employees, state-owned, agriculture, village or small town. 
Table 5. The average of three indicators by sectors

\begin{tabular}{|l|c|c|c|}
\hline \multirow{2}{*}{} & Job loss & Zero hours worked & Telework \\
\cline { 2 - 4 } & $\begin{array}{c}\text { Number of jobs in } \\
\text { January-February }=\mathbf{1 0 0}\end{array}$ & $\begin{array}{c}\text { Number of jobs in } \\
\text { April-June }=\mathbf{1 0 0}\end{array}$ & $\begin{array}{c}\text { Number of active jobs in } \\
\text { April-June }=\mathbf{1 0 0}\end{array}$ \\
\hline Services & 7.2 & 10.6 & $\mathbf{3 1 . 6}$ \\
\hline Trade & 6.7 & 6.9 & 9.5 \\
\hline Motor industry & 6.2 & 16.0 & 8.2 \\
\hline Construction & 5.5 & 6.6 & 6.0 \\
\hline Public administration & 4.6 & 5.0 & 14.6 \\
\hline Other industry, energy & 4.5 & 6.4 & 7.8 \\
\hline Healthcare & 4.2 & 10.0 & 6.9 \\
\hline Agriculture & 3.3 & 2.5 & 3.2 \\
\hline Education & 3.0 & 6.7 & 51.2 \\
\hline Transportation & 2.9 & 7.1 & 8.4 \\
\hline Communal services & 2.4 & 4.6 & 15.7 \\
\hline
\end{tabular}

Source: Version of the LFS of the HCSO maintained by the CERS Databank.

Note: Active job $=$ more than zero hours worked.

Table 6. The average of three indicators by educational attainment

\begin{tabular}{|l|c|c|c|}
\hline & Job loss & Zero hours worked & Telework \\
\cline { 2 - 4 } & $\begin{array}{c}\text { Number of jobs in } \\
\text { January-February } \mathbf{1 0 0}\end{array}$ & $\begin{array}{c}\text { Number of jobs in } \\
\text { April-June }=\mathbf{1 0 0}\end{array}$ & $\begin{array}{c}\text { Number of active jobs in } \\
\text { April-June = 100 }\end{array}$ \\
\hline 0-8 grades & 10.7 & 7.2 & 0.9 \\
\hline Vocational school & 5.2 & 7.9 & 1.2 \\
\hline Gymnasium & 5.6 & 10.0 & 11.3 \\
\hline Vocational upper-secondary & 5.0 & 8.0 & 9.5 \\
\hline College & 3.4 & 7.4 & 37.3 \\
\hline University & 2.4 & 5.4 & 49.7 \\
\hline
\end{tabular}

Source: Version of the LFS of the HCSO maintained by the CERS Databank.

Note: Active job $=$ more than zero hours worked. 


\section{REVENUES}

\subsection{Definitions and measurement}

This section relies on a revenue statistics survey, which provides information on the interim changes in firm revenue. The survey is primarily aimed at manufacturing firms, including mining, processing industries, energy, water supply and construction (Categories B-F of TEÁOR/NACE Rev.2). Firms have to submit the related questionnaire until the twentieth day of the following month; thus, the survey provides almost real-time information about the revenues of manufacturing firms. The selected firms participate both in the monthly and quarterly surveys. The two surveys are strongly related ${ }^{10}$, but the questions are not entirely identical. This paper uses data from the period between January 2011 and August 2020. ${ }^{11}$

The performance of firms is most often measured using value-added, which is the difference between net revenue and material cost. However, this study is only able to analyse the changes in monthly turnover because the questionnaire only quarterly asks relatively big firms (over 50 employees) about material costs.

Since we measure firms' activity with revenue, their actual performance is overestimated at the aggregate level. Consider the following example, if a product appears at two companies in the production chain, its value is taken into account twice in the industry's total revenue. For example, soft drink bottlers do not usually manufacture bottles but buy them from other firms. Consequently, the bottle appears in the sales revenues of both the bottle manufacturer and the soft drink producer.

Nevertheless, when assessing the impact of the crisis at the enterprise level, the lack of information on monthly material costs does not cause a considerable problem. Reizer (2020) found that a one percent change in revenues is associated with a $0.9 \%$ change in the material costs. Accordingly, we expect that turnover and added value changed to a similar extent during the pandemic. ${ }^{12}$

Similar to the LFS, sampling is of primary importance in revenue statistics. The survey includes all firms with more than 50 employees and a random sample of firms with 5-50 workers. Firms with fewer than 50 employees participate from January to December each year and are replaced by another random sample following January. If a firm does not submit the questionnaire in any of the months, the HCSO requests them to file the missing documents. Efforts to obtain the missing data continue after the end of the reference year; therefore, the results from 2020 cannot be considered final.

Due to the survey design, the attrition rate before the pandemic was low, $2 \%$ in the unweighted sample and $3 \%$ if we weight smaller firms to ensure representatively. During the lockdown, the rates amounted to $5 \%$ and $9 \%$, respectively. The difference shows that the smaller businesses were more likely to drop out of the sample.

\footnotetext{
${ }^{10}$ For example, enterprises can report quarterly turnover, which equals the total of three-months turnover.

${ }^{11}$ We do not include data from 2010 so that the estimates presented below are not distorted by the financial crisis. Data from September 2020 are not yet available.

${ }^{12}$ We can calculate value added only for firms with more than 50 employees that is why we do not show the corresponding estimates. Still, the results are similar on this subsample as well.
} 
The higher attrition rate may be due to two factors. On the one hand, as a result of the crisis, firms were more likely to go bankrupt. On the other hand, the government allowed enterprises to fulfil their reporting obligations belatedly as a part of the crisis management package. As a result, some operating businesses simply did not submit the questionnaire. The relative importance of the two factors can be determined only when information on the actual bankruptcies from other databases becomes available. However, it is unlikely that only the change in reporting behaviour causes the increase in attrition for two reasons. Firstly, attrition also increased during the crisis in 2009 , although companies were not exempted from completing the questionnaire $^{13}$. Secondly, we do not find any companies that returned to the sample during the summer, when the economy started to recover.

The performance statistics do not contain a sufficient number of observations to assess the impact of the crisis by industries. Therefore, we classify businesses into four groups based on their exporting status (yes/no) and ownership (Hungarian/foreigner). The justification was that the measures introduced to contain the COVID pandemic impaired international transportation and caused difficulties for the exporting companies. Additionally, several studies (e.g., Commander - Svejnar 2011; Earle et al. 2018) found that the foreign-owned companies are in many respects better than the domestic ones: they have more employees, higher revenues and productivity. Therefore, we can assume that these businesses can better adapt to unexpected shocks.

Controlling for seasonality is crucial for assessing the impact of the crisis, as there is a strong seasonality in turnover (see Fig. 2). There are two major approaches for controlling for seasonality: applying time series seasonal filters and regression analysis. The first approach relies on time series methods like the TRAMO-SEATS method used to characterise each firm individually (Maravall 2016). This was not feasible for us because we observe smaller firms for only a year. Therefore, we rely on regression analysis to control for seasonality by estimating the following equation:

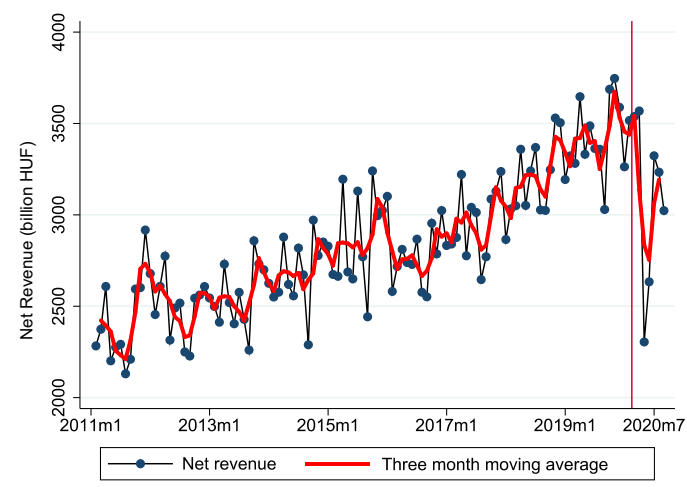

Fig. 2. Sales revenues of manufacturing firms in 2011-2020

Source: Authors' calculations, based on monthly revenue statistics.

${ }^{13}$ Attrition was $9.7 \%$ in 2008 and $8.8 \%$ in 2009 . 


$$
\begin{aligned}
& \text { (1) } y_{i t}=\beta_{0}(\text { year }=2020)+\beta_{1} \text { sector }_{i}^{*}(\text { year }=2020)+\beta_{2} X_{i t} *(\text { year }=2020)+\beta_{3} \text { sector }_{i} \\
& +\beta_{4} X_{i t}+\varepsilon_{i t}
\end{aligned}
$$

The dependent variable is the outcome of firm $i$ in month $t$. We analyse four different outcomes: attrition and change in revenue between February and April and February and July. The first period reveals the immediate effect of the lockdown, whereas the second indicates the extent of recovery. The variable sector ${ }_{i}$ shows which group the firm belongs to, is based on exporting status and ownership. $X_{i t}$ contains control variables, which are obtained from balance sheet data and the Wage Survey and then merged to the revenue statistics. Importantly, we merge to each observation a lagged (one-year earlier) observation ${ }^{14}$. The advantage of the method is that the lagged control variables had not yet been affected by the crisis, and therefore, it was possible to minimize the bias of reverse causality.

In this specification, $\beta_{3}$ and $\beta_{4}$ measure the average interim changes of earlier years to control for seasonality, while $\beta_{1}$ and $\beta_{2}$ indicate the impact of the crisis. For example, if the dependent variable is the change in turnover between February and April, then $\beta_{3}$ shows the average increase between February and April in 2011 and 2019 in the various enterprise categories, while $\beta_{4}$ indicates how much increased the seasonally adjusted revenue between February and April 2020.

It is essential to note that the four sector dummies denoted by $\beta_{1}$ and the year dummy $\left(\beta_{0}\right)$ cannot be estimated together because of perfect multicollinearity. Consequently, the Hungarianowned non-exporting firms are excluded from the regression. In this way, the parameter $\beta_{1}$ indicates the performance of the other sectors relative to the Hungarian-owned non-exporting firms. Parameter $\beta_{0}$ is also economically meaningful if no other control variable is used apart from the sector variables. In this case $\beta_{0}$ shows to what extent the performance of the Hungarian-owned, non-exporting sector changed in 2020 compared to the previous years.

\subsection{Factors affecting the attrition of firms}

We start investigating firm behaviour by exploring attrition since some dropout firms went bankrupt and those staying in the sample operated without a doubt. This selection effect has to be taken into account when assessing trends in turnover figures.

The first column of Table 7 shows that the attrition rate was 1.5 percentage points higher among the Hungarian-owned exporting and non-exporting firms between February and April 2020 than in the similar period of earlier years. This is a significant increase, as the attrition rate did not reach 3 percentage points in the preceding years. However, the parameter of -0.0148 of the foreign-owned exporting firms indicates that attrition did not increase in this group.

Column (2) explores to what extent attrition and other characteristics of firms are associated. The findings suggest that one of the most critical indicators is firm size (the number of workers). The respective parameter shows that if the firm's size is $10 \%$ larger, the attrition rate is 0.073 percentage points higher. As the database contains both small enterprises with five employees and large ones with hundreds, the parameter indicates substantial heterogeneity across firms.

\footnotetext{
${ }^{14}$ The only exception is 2020 , where only data from 2018 is provided, since balance sheet and Wage Survey data from 2019 is not yet available.
} 
Table 7. Attrition of firms between February and April 2020

\begin{tabular}{|c|c|c|c|c|}
\hline & \multicolumn{2}{|c|}{ Between February and April } & \multicolumn{2}{|c|}{ Between February and July } \\
\hline & (1) & (2) & (3) & (4) \\
\hline \multirow[t]{2}{*}{ Foreign-owned - exporting } & $-0.0148^{* *}$ & 0.0014 & $-0.0695^{* * *}$ & 0.0092 \\
\hline & $(0.0062)$ & $(0.0072)$ & $(0.0093)$ & $(0.0111)$ \\
\hline \multirow[t]{2}{*}{ Foreign-owned - not exporting } & $-0.0411^{*}$ & -0.0288 & 0.0030 & 0.0523 \\
\hline & $(0.0222)$ & $(0.0237)$ & $(0.0401)$ & $(0.0417)$ \\
\hline \multirow[t]{2}{*}{ Domestic - exporting } & -0.0056 & 0.0029 & $-0.0475^{* * *}$ & -0.0083 \\
\hline & $(0.0067)$ & $(0.0069)$ & $(0.0100)$ & $(0.0104)$ \\
\hline \multirow[t]{2}{*}{ Dummy for year $2020^{1}$} & $0.0151^{* *}$ & 0.0273 & $0.0795^{* * *}$ & $0.428^{* * *}$ \\
\hline & $(0.0059)$ & $(0.0704)$ & $(0.0085)$ & $(0.0860)$ \\
\hline \multirow[t]{2}{*}{ Share of graduates } & & $-0.0520^{* *}$ & & $-0.0626^{*}$ \\
\hline & & $(0.0230)$ & & $(0.0360)$ \\
\hline \multirow[t]{2}{*}{ Share of gymnasium graduates } & & 0.00529 & & -0.0118 \\
\hline & & $(0.0220)$ & & $(0.0310)$ \\
\hline \multirow[t]{2}{*}{ Share of skilled workers } & & 0.0042 & & 0.0250 \\
\hline & & $(0.0182)$ & & $(0.0293)$ \\
\hline \multirow[t]{2}{*}{ Log(headcount) } & & $-0.0073^{* * *}$ & & $-0.0302^{* * *}$ \\
\hline & & $(0.0025)$ & & $(0.0037)$ \\
\hline \multirow[t]{2}{*}{ Log(wage cost/headcount) } & & -0.0031 & & $-0.0297^{* *}$ \\
\hline & & $(0.0101)$ & & $(0.0123)$ \\
\hline \multirow[t]{2}{*}{ Log(turnover/headcount) } & & 0.0038 & & 0.0036 \\
\hline & & $(0.0035)$ & & $(0.0049)$ \\
\hline \multirow[t]{2}{*}{ Physical presence } & & 0.0088 & & $-0.1080^{*}$ \\
\hline & & $(0.0399)$ & & $(0.0575)$ \\
\hline Control variables & No & Yes & No & Yes \\
\hline Observations & 32,255 & 31,875 & 32,255 & 31,875 \\
\hline$R$-squared & 0.035 & 0.032 & 0.056 & 0.052 \\
\hline
\end{tabular}

Note: ${ }^{1}$ The reference group shows the increase within the category of domestic, not exporting firms without control variables. If control variables are included, it cannot be interpreted. 
According to the table, productivity (revenue per employee) and wage levels (wage costs per person) are no longer correlated with the probability of attrition if we control for company size.

When examining the composition of employees, it is seen that only the share of university graduates impacts the probability of attrition. If the proportion of graduates was $10 \%$ higher, the probability of attrition was 0.5 percentage points lower between February and April 2020. This finding is consistent with the results of the LFS, which found that a smaller proportion of graduates lost their jobs.

Column (3) investigates to what extent the positive effect of graduates is due to telework. For this purpose, we rely on the American $\mathrm{O}^{*} \mathrm{Net}$ database. The database determines to what extent physical presence is required for performing a job $(0=$ it may be undertaken anywhere, $1=$ the work can only be performed at the site of the firm). We merged this indicator to the Wage Survey at the level of occupations and calculated an average indicator on the firm level ${ }^{15}$. The parameter shows that attrition is higher by 0.85 percentage points if the indicator is higher by one standard deviation as well ${ }^{16}$. However, the presence index is highly correlated with educational categories thus the parameter is imprecisely estimated.

It is important to note that the parameters of sector dummies in column 2 are no longer statistically significant. This indicates that domestic firms were more likely to drop out because they were smaller and employed a smaller proportion of higher education graduates.

Columns (3) and (4) present attrition between February and July. Column (3) indicates that even though the lockdown had been terminated by July, attrition among the Hungarian-owned, not exporting firms was nearly $7.95 \%$. This rate is substantially higher than that of the exporting firms. The result suggests that bankruptcy was more frequent in this group, and the impact of the crisis lasted longer. The last column of the table shows that, if controlling for headcount, the difference between sectors disappears. Moreover, the headcount parameter is four times as high as the parameter between February and April (0.007 vs 0.03). Surprisingly, however, the probability of attrition is not associated with either the share of higher education graduates or the index measuring physical presence.

\subsection{Factors influencing changes in revenues}

After analysing attrition, we examine revenues. The first column of Table 8 shows that the revenues of domestic non-exporters fell by $22.4 \%$ between February and April 2020. Foreignowned exporting companies experienced an even more significant decrease in income: the decline was $25 \%$ larger among them. The other columns indicate that this difference remains if we control for the composition effect. In the absence of data, it is difficult to identify the exact reason for this extraordinarily large drop. The most likely explanation is that the border restrictions introduced due to the COVID pandemic cut these firms off from their foreign markets.

The inclusion of further control variables reveals that firm size and the proportion of higher education graduates also played an essential role in this period. With a $1 \%$ larger

\footnotetext{
${ }^{15}$ The merging procedure relied on the codes of Koren - Petö (2020). If a firm is not included in the Wage Survey, we use the industry level average instead.

${ }^{16}$ The standard deviation of the physical presence variable is 0.2 in the database.
} 
Table 8. Change in revenue between February and April 2020

\begin{tabular}{|c|c|c|c|c|c|c|}
\hline & \multicolumn{3}{|c|}{ Between February and April } & \multicolumn{3}{|c|}{ Between February and July } \\
\hline & (1) & (2) & (3) & (4) & (5) & (6) \\
\hline \multirow[t]{2}{*}{ Foreign-owned, exporting } & $-0.257^{* * *}$ & $-0.242^{* * *}$ & $-0.246^{* * *}$ & $0.089^{* *}$ & 0.061 & 0.051 \\
\hline & $(0.046)$ & $(0.054)$ & $(0.053)$ & $(0.040)$ & $(0.048)$ & $(0.046)$ \\
\hline \multirow[t]{2}{*}{ Foreign-owned, not exporting } & 0.0165 & -0.041 & -0.008 & 0.165 & 0.012 & -0.012 \\
\hline & $(0.138)$ & $(0.141)$ & $(0.138)$ & $(0.113)$ & $(0.111)$ & $(0.104)$ \\
\hline \multirow[t]{2}{*}{ Domestic, exporting } & -0.038 & -0.023 & -0.027 & $0.079^{* *}$ & $0.070^{*}$ & $0.077^{* *}$ \\
\hline & $(0.041)$ & $(0.043)$ & $(0.042)$ & $(0.040)$ & $(0.041)$ & $(0.039)$ \\
\hline \multirow[t]{2}{*}{ Dummy for year $2020^{1}$} & $-0.224^{* * *}$ & $-0.794^{* *}$ & $-0.783^{* *}$ & $-0.232^{* * *}$ & -0.516 & $-0.890^{* * *}$ \\
\hline & $(0.035)$ & $(0.368)$ & $(0.353)$ & $(0.035)$ & $(0.333)$ & $(0.314)$ \\
\hline \multirow[t]{2}{*}{ Share of graduates } & & $0.334^{* *}$ & $0.388^{* *}$ & & -0.028 & 0.034 \\
\hline & & $(0.168)$ & $(0.164)$ & & $(0.140)$ & $(0.137)$ \\
\hline \multirow[t]{2}{*}{ Share of gymnasium graduates } & & 0.153 & 0.164 & & 0.106 & 0.153 \\
\hline & & $(0.148)$ & $(0.142)$ & & $(0.129)$ & $(0.124)$ \\
\hline \multirow[t]{2}{*}{ Share of skilled workers } & & 0.150 & 0.165 & & 0.099 & 0.106 \\
\hline & & $(0.133)$ & $(0.130)$ & & $(0.109)$ & $(0.105)$ \\
\hline \multirow[t]{2}{*}{ Log(headcount) } & & $-0.037^{* *}$ & $-0.031^{* *}$ & & -0.003 & $0.023^{*}$ \\
\hline & & $(0.015)$ & $(0.015)$ & & $(0.013)$ & $(0.012)$ \\
\hline \multirow[t]{2}{*}{ Log(wage cost/headcount) } & & 0.065 & 0.063 & & 0.041 & 0.074 \\
\hline & & $(0.052)$ & $(0.049)$ & & $(0.048)$ & $(0.046)$ \\
\hline \multirow[t]{2}{*}{ Log(turnover/headcount) } & & -0.001 & -0.003 & & 0.012 & 0.003 \\
\hline & & $(0.022)$ & $(0.021)$ & & $(0.020)$ & $(0.019)$ \\
\hline
\end{tabular}


Table 8. Continued

\begin{tabular}{|c|c|c|c|c|c|c|}
\hline & \multicolumn{3}{|c|}{ Between February and April } & \multicolumn{3}{|c|}{ Between February and July } \\
\hline & (1) & (2) & (3) & (4) & (5) & (6) \\
\hline \multirow[t]{2}{*}{ Physical presence } & & 0.039 & 0.012 & & $-0.442^{*}$ & \\
\hline & & $(0.272)$ & $(0.267)$ & & $(0.253)$ & $(0.246)$ \\
\hline Control variables & No & Yes & Yes & No & Yes & Yes \\
\hline Dropout firms ${ }^{2}$ & excluded & excluded & $-50 \%$ & excluded & excluded & $-50 \%$ \\
\hline Observations & 31,485 & 31,136 & 31,875 & 31,213 & 30,875 & 31,875 \\
\hline$R$-squared & 0.046 & 0.058 & 0.048 & 0.066 & 0.083 & 0.069 \\
\hline
\end{tabular}

Notes: ${ }^{1}$ The reference group shows the increase within the category of domestic, not exporting firms without control variables. If control variables are included, it cannot be interpreted.

${ }^{2}$ Dropout firms are either excluded or coded with a $50 \%$ or $80 \%$ decline in turnover. 
employment, revenue fell by $0.03 \%$ less. Nevertheless, this relationship remains qualitatively the same if we assume that the sales revenues of the dropout firms declined by $80 \%$ on average. ${ }^{17}$

The parameter for higher education graduates indicates that the turnover of enterprises with a $1 \%$ higher share of higher education graduates increased revenues by $0.3-0.4 \%$ less. The result is robust to the inclusion of other control variables or the treatment of dropout firms.

Columns (4) to (6) cover the period of February-July and the extent of recovery. The first column indicates that the revenue of domestic non-exporters did not recover at all. Revenue in this group remained 25\% below the revenue in February. Exporting firms were able to grow to some extent: their revenue was only $23-8=15 \%$ below their output in February. Their performance improved significantly but did not reach the February level.

In addition, the parameter estimates remain significantly positive for domestic exporters even when including additional control variables. This implies that the relative recovery of turnover was not associated with firm characteristics but with the expansion of export markets.

Finally, the impact of firm size is worth taking a closer look. No negative correlation is found between employment and turnover if the dropout firms are excluded while, there is a positive correlation between the increase in turnover and firm size if we presume that the average turnover of the dropout firms declined by $50 \%$ or $80 \%$.

To better understand, we estimate the change of revenue for February-July 2019 and 2020 as a function of employment (Fig. 4). The circles imply that attrition does not correlate with changes in turnover, while the rhombuses suppose that the turnover of the dropout firms fell by $80 \%$.

Data from 2019 show strong seasonality. Revenues in July are lower in all firm size categories than in February, but there is no strong correlation between firm size and changes in turnover. This pattern is not substantially modified even when attrition is assumed to correlate strongly with the fall in revenues. The reason is that there were very few enterprises with more than ten employees that dropped out in 2019 (Fig. 3).

By contrast, in 2020, attrition has a more critical role. On the one hand, no association is observed between increase in revenue and firm size if attrition is not controlled for. On the other hand, the small enterprises were unable to recover during summer, if we suppose that the turnover of the dropout enterprises decreased significantly. Unfortunately, relying only on available data, we cannot test which assumption is valid. We think the second assumption may be closer to the reality (marked with rhombuses), since firms are more likely to drop out in month $t+2$ every year if they suffered a significant fall in turnover between months $t$ and $t+1$. The corresponding results are available upon request.

\section{CONCLUSIONS}

The lockdown introduced during the first wave of the pandemic and the accompanying supply and demand-side disturbances affected the Hungarian labour market and the firms even more seriously than the $2008-2010$ crisis. As a result of dismissals and working time reductions, the

\footnotetext{
${ }^{17}$ If the dropout firms were simply excluded, it would implicitly suggest that attrition is unrelated to changes in turnover. This assumption is probably not true for last year's crisis.
} 
Unweighted time series

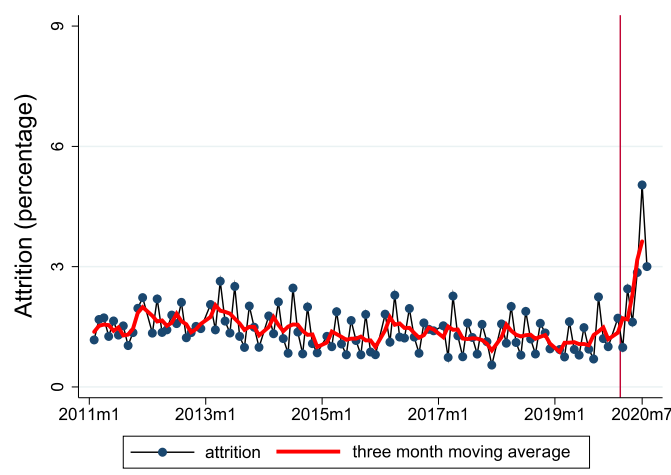

Weighted time series

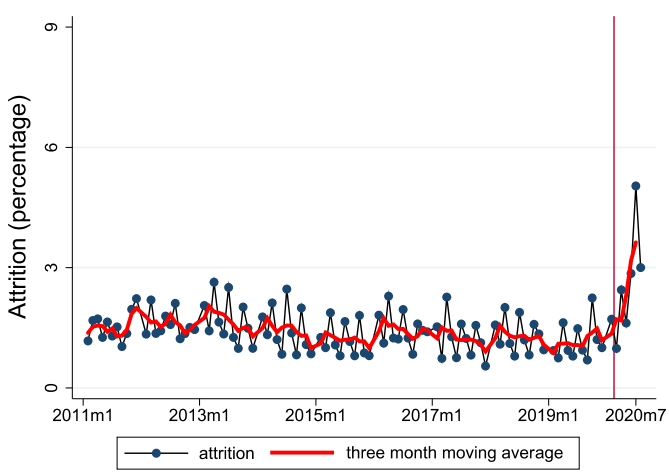

Fig. 3. Aggregate attrition in the revenue statistics survey Source: Authors' calculation, based on the performance statistics survey of the HCSO. Note: The attrition in December is calculated as an average of the attrition in November and January.

Increase in 2019

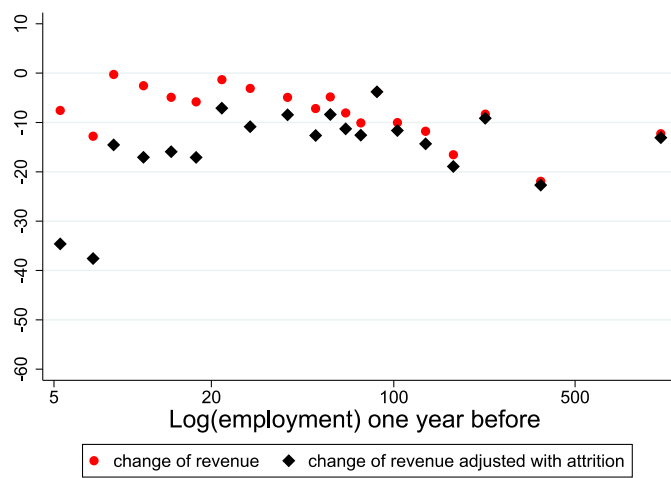

Increase in 2020

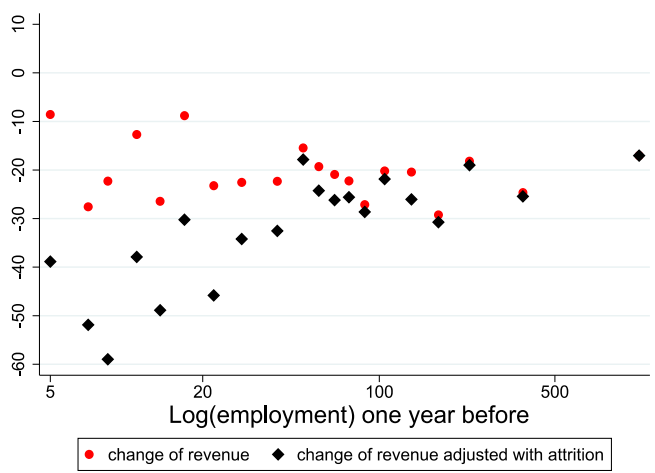

Fig. 4. Change in revenue between February and July Source: Authors' calculation based on the revenue statistic survey of the HCSO.

number of employees working at least one hour fell by $7.6 \%$, and the full-time equivalent employment dropped by $9 \%$ in the second quarter, compared to January-February. At the same time, industrial production plummeted by $30 \%$ in one month, which was also considerably more severe than the $20 \%$ total annual decline in 2008.

The usual aggregate indicators regularly published in the media underestimate the extent of the shock to employment because they disregard the nearly $6 \%$ decline in working time. Conventional unemployment data are not more informative either, since many dismissed workers may have hoped the lockdown would end, which reduced their willingness to look for a job or register as unemployed. The extremely high attrition rate we found in the revenue survey is worrying. If firms dropping out of the sample went bankrupt, then recovery chances are considerably reduced. 
The crisis significantly increased income inequality which was very high even before the pandemic. The job loss rate was highest in low-qualified groups, and less productive and smaller domestic firms suffered a more significant loss. These impacts are not unprecedented since several countries experienced similar trends (Buchheim et al. 2020; Kozeniauskas et al. 2020; Bloom et al. 2021). Working-time reductions were also widely used throughout Europe, and young people were heavily exposed to the crisis in most countries (OECD 2020).

The data suggest that the issue of telework is exaggerated in the discourse about the longterm consequences of the pandemic. More than $40 \%$ of the Hungarian working-age population has lower-secondary or vocational school qualifications. For them, the crisis only brought on what previous crises had: losing their jobs or at least their daily work. Working from home is an option for few workers with upper-secondary qualifications (who constitute one-third of the population): one out of ten worked at home during the first wave of the pandemic. Zoom meetings and Teams conferences became a part of life - in many cases temporarily - only for one-third of the college graduates and half of those holding a university diploma.

\section{REFERENCES}

Bloom, N. - Fletcher, R. S. - Yeh, E. (2021): The Impact of COVID-19 on US Firms. NBER Working Paper, No. 28314.

Buchheim, L. - Dovern, J. - Krolage, C. - Link, S. (2020): Firm-level Expectations and Behavior in Response to the COVID-19 Crisis. CESifo Working Paper, No. 8304.

Commander, S. - Svejnar, J. (2011): Business Environment, Exports, Ownership, and Firm Performance. The Review of Economics and Statistics, 93(1): 309-337.

Cseres-Gergely, Zs. (2011): Munkapiaci áramlások, konzisztencia és gereblyézés (Employment Flows, Consistency, and Raking). Statisztikai Szemle, 89(5): 481-500.

Earle, J. S. - Telegdy, Á. - Antal, G. (2018): Foreign Ownership and Wages: Evidence from Hungary, 19862008. Cornell University, ILR Review, 71(2): 458-491. https://doi.org/10.1177/0019793917700087.

Koren, M. - Pető, R. (2020): Business Disruptions from Social Distancing. PloS One, 15(9): e0239113. https://doi.org/10.1371/journal.pone.0239113.

Kozeniauskas, N. - Moreira, P. - Santos, C. (2020): COVID-19 and Firms: Productivity and Government Policies. CEPR Discussion Paper, No. DP15156.

Maravall, A. (2016): Quality of Seasonal Adjustment in the Model-Based Approach of TRAMO-SEATS. Eurostat Handbook, (Part III).

Mihályffy, L. (1995): Meghiúsulások kompenzálása lakossági felvételekben: Egy speciális lineáris inverz probléma (Compensation of Non-Responses in Population Surveys: A Special Linear Inverse Problem). Szigma, 25(4): 191-202.

Molnár, Gy. (2005): Az adatállomány és a rotációs panel (The Data Content and the Rotating Panel). In: Kapitány Zs - Molnár, Gy - Virág, I. (eds): Háztartások a tudás- és munkapiacon (Households and Knowledge in the Labour Market). MTA KTI, Budapest, pp. 141-147.

OECD (2020): OECD Employment Outlook - Facing the Jobs Crisis. http://www.oecd.org/employmentoutlook $/ 2020 /$.

Reizer, B. (2020): Flexible Wages, Employment and Efficiency. Manuscript. 


\section{APPENDIX}

\begin{tabular}{|l|c|c|c|}
\hline \multicolumn{5}{|l|}{ Observations in the LFS (persons) } & January-February & March & April-June \\
\hline & 34,065 & 14,157 & 42,813 \\
\hline Total & 24,639 & 10,698 & 32,481 \\
\hline $14-74$ years & 20,500 & 8,552 & 25,981 \\
\hline $15-64$ years & 18,353 & 7,755 & 23,870 \\
\hline $15-64$ years, not in full-time education & & &
\end{tabular}

Source: Version of the LFS of the HCSO maintained by the CERS Databank. 